\title{
Small Airways Disease and Asthma Management: Is there a Connection?
}

Federico Bellini, MD, Luca Morandi, MD and Alberto Papi, MD, FERS

Research Centre on Asthma and COPD, Department of Medical Sciences, University of Ferrara, Ferrara, Italy

\section{ABSTRACT}

We reviewed literature on the assessment and prevalence of small airways impairment in asthma and the relationships between small airways disease (SAD) and asthma clinical characteristics. The effects of treatments targeting small airways alterations are also discussed. We performed a PubMed search, using "asthma AND small airways" and "small airways AND treatment". All identified works were reviewed for adequacy, including reviews, randomised clinical trials and real-life studies. We found evidence that SAD is highly prevalent in the asthma population, throughout all degrees of severity. SAD seems particularly pronounced in some specific phenotypes and in severe asthma. Further studies are needed to investigate the mechanisms of the association between SAD and clinical outcomes such as symptom control and exacerbation risk. The inhaled treatment with recently developed small particle size formulations warrants a greater drug deposition in the more peripheral district and positively affects clinical outcomes while reducing the overall drug exposure. (BRN Rev. 2018;:16-33)

Corresponding author: Alberto Papi, ppa@unife.it

Key words: Asthma. Extra fine particles. Phenotypes. Small airways. 


\section{INTRODUCTION}

Asthma is a common condition, usually characterised by chronic inflammation of the airways ${ }^{1}$. It is a clinically heterogeneous disease, involving many elements in determining the variability that characterises the clinical presentation of the disease. In past years, many efforts were made to identify clusters of patients who share common demographic, clinical and/or pathophysiological characteristics, which have been termed asthma phenotypes ${ }^{2,3}$. In this context, several investigators have questioned the relevance of pathophysiological changes in the more peripheral divisions of the airways and whether they are associated with specific clinical presentation and/or susceptibility to treatment. Indeed, despite being considered for a long time a disease primarily affecting central airways, it is now well documented that profound rearrangements occur in the distal areas of the airways of asthmatic patients ${ }^{1}$.

Small airways were defined in the 1970s as the partition of airways with a diameter $<2 \mathrm{~mm}$, without cartilage in their walls and originating from the eighth bronchial division down to the respiratory bronchioles ${ }^{4}$. In past years, they have been termed the silent zone of the lung, in relation to the difficulty of evaluation with conventional methods and to the supposed relatively low contribution to total airway resistance ${ }^{5}$. In recent years, the pathophysiology of small airways and of their role in clinical outcomes of asthma has been more systematically addressed with the development of diagnostic tools investigating the peripheral district from different viewpoints.

\section{ASSESSING SMALL AIRWAYS DISEASE IN ASTHMA: OVERVIEW AND PREVALENCE}

The analytical description of the instruments that have been used to investigate small airways in asthma has been the specific objective of recent reviews to which we refer for additional details.

Bronchioles, terminal bronchioles and alveolar ducts/sacs are the main structures considered as small airways (Fig. 1). They are characterized by diameter $<2 \mathrm{~mm}$, a large cross-sectional area of about $140 \mathrm{~m}^{2}$ and a volume of approximately $4,500 \mathrm{ml}$ that accounts for $98.8 \%$ of the total lung volume ${ }^{6}$. In asthma with small airways disease (SAD), an increase in airway smooth muscle mass, mucus plugging, and goblet cell hyperplasia is present in the most peripheral part of the lung with an inflammatory cellular profile mainly characterized by infiltration of mast cells, eosinophils and CD4 Th2 lymphocytes ${ }^{7,8}$.

The pathology of small airways in asthma has been mainly assessed in surgical/autoptic specimens or transbronchial biopsies ${ }^{9}$. These studies showed increased inflammation and substantial rearrangement of peripheral airways with altered composition of bronchiolar walls and of alveolar attachments with reduction in elastic fibre content. However, most of these data refer to severe asthma or asthma deaths, and limited information is available in mild asthma conditions $^{8,10-12}$.

The pathophysiology of SAD has been studied via invasive endobronchial catheterisation 


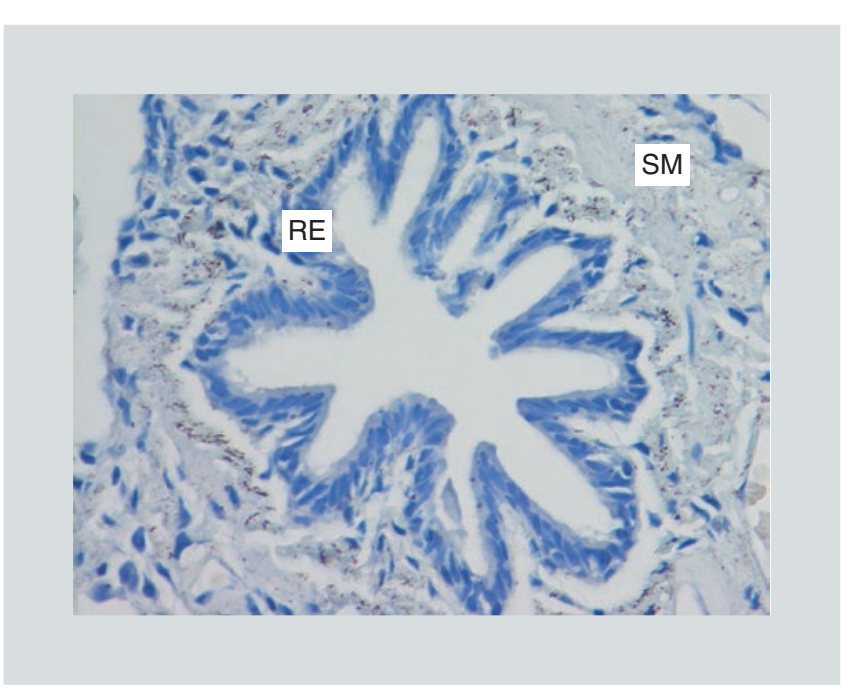

Figure 1. Section highlighting small airways. RE: respiratory epithelium; SM: smooth muscle.

in asthmatic patients, documenting significantly increased resistance in the peripheral airways of asthmatic patients when compared to non-asthmatic controls, with higher resistance detected in patients with airflow obstruction ${ }^{4,5,13,14}$.

Seminal physiology studies based on inert gas technique suggested that small airways impairment in asthma can lead to ventilation-perfusion inequality even in asymptomatic patients with normal spirometry ${ }^{15,16}$. In patients with ventilation-perfusion mismatch due to SAD, gas exchange might not deteriorate until forced expiratory volume in $1 \mathrm{sec}-$ ond $\left(\mathrm{FEV}_{1}\right)$ reaches about $40 \%$ of predicted, and after that, gas exchange can rapidly worsen ${ }^{17}$. Spirometric data alone have therefore been suggested to have poor correlations with small airways alterations and may not clearly identify patients liable to serious gas exchange deterioration.

In recent years, several diagnostic tools have been developed to investigate small airways abnormalities noninvasively with different approaches, from lung function to imaging and to inflammatory markers, providing information on different aspects of small airways impairment (Table 1).

Spirometry and plethysmography can provide some indices related to SAD and the associated gas trapping and lung hyperinflation. Increased residual volume (RV), ratio between RV and total lung capacity (RV/TLC) and increased difference between slow and forced vital capacity (SVC-FVC), as well as decreased FVC, decreased forced expiratory flow at 25-75\% $\left(\mathrm{FEF}_{25-75 \%}\right)$ and $50 \%$ of forced vital capacity $\left(\mathrm{FEF}_{50 \%}\right)$, have been considered as markers of small airways dysfunction. Their use is limited given their high physiological variability and because they are considered rough estimations of premature airway closure 18-24. $^{1}$

The single-breath nitrogen washout $\left(\mathrm{SBN}_{2} \mathrm{~W}\right)$ test can assess ventilation inhomogeneity and early closure of peripheral airways due to small airways dysfunction (phase III slope: $\mathrm{dN}_{2}$, closing volume [CV], closing capacity [CC]) after a single inspiration of $100 \%$ oxygen from RV to $\mathrm{TLC}^{25}$.

The multiple-breath nitrogen wash-out (MB$\mathrm{N}_{2} \mathrm{~W}$ ) test is performed by the inhalation of $100 \%$ oxygen during tidal breathing ${ }^{26}$. It is a highly reproducible technique based on the rate and the extent of $\mathrm{N}_{2}$ gas exhalation from the tracheobronchial tree, reflecting changes in lung ventilation in the whole lung, in proximal and conducting airways and in distal and acinar regions (Scond, Sacin) ${ }^{27,28}$.

Forced oscillation technique (FOT) and impulse oscillometry (IOS) are effort-independent tests performed during tidal breathing that need 
TABLE 1. Techniques used to assess small airways function

\begin{tabular}{|c|c|c|c|c|}
\hline Test & Measures & Outcomes & Pros & Cons \\
\hline Spirometry & $\begin{array}{l}\mathrm{FEF}_{25-75}, \mathrm{FVC}, \mathrm{SVC} / \mathrm{FVC} \text {. (i.e. } \\
\text { SVC minus FVC, see ref. 18) }\end{array}$ & $\begin{array}{l}\text { Gas trapping, ventilation } \\
\text { heterogeneity }\end{array}$ & $\begin{array}{l}\text { Non-invasive, easy to } \\
\text { perform, widely } \\
\text { available, low costs }\end{array}$ & $\begin{array}{l}\text { Influenced by central airways } \\
\text { obstruction and volume } \\
\text { changes, not very specific for } \\
\text { SAD, poor reproducibility }\end{array}$ \\
\hline Body plethysmography & TLC, FRC, RV, RV/TLC & $\begin{array}{l}\text { Gas trapping, ventilation } \\
\text { heterogeneity }\end{array}$ & $\begin{array}{l}\text { Non-invasive, easy to } \\
\text { perform, low variability, } \\
\text { fair reproducibility }\end{array}$ & Further studies required \\
\hline FOT/IOS & $\begin{array}{l}\text { R5-R2O, reactance at } 5 \mathrm{~Hz} \\
(\mathrm{X} 5) \text {, reactance area }(\mathrm{AX})\end{array}$ & $\begin{array}{l}\text { Peripheral airways } \\
\text { obstruction, resistance } \\
\text { and capacitance }\end{array}$ & $\begin{array}{l}\text { Non-invasive, easy } \\
\text { to perform, fair } \\
\text { reproducibility }\end{array}$ & Not widely available \\
\hline $\mathrm{MBN}_{2} \mathrm{~W}$ & Sacin, Scond & $\begin{array}{l}\text { Gas trapping, acinar and } \\
\text { conductive ventilation } \\
\text { heterogeneity }\end{array}$ & $\begin{array}{l}\text { Non-invasive, good } \\
\text { sensitivity, good } \\
\text { reproducibility }\end{array}$ & Not widely available \\
\hline $\mathrm{SBN}_{2} \mathrm{~W}$ & $\begin{array}{l}\text { Closing volume, closing } \\
\text { capacity, Phase III slope }\end{array}$ & $\begin{array}{l}\text { Gas trapping, ventilation } \\
\text { heterogeneity }\end{array}$ & $\begin{array}{l}\text { Non-invasive, good } \\
\text { sensitivity, good } \\
\text { reproducibility }\end{array}$ & Not widely available \\
\hline Exhaled NO & FeNO, CalvNO & $\begin{array}{l}\text { Inflammation, remodelling } \\
\text { of } S A D\end{array}$ & $\begin{array}{l}\text { Non-invasive, fair } \\
\text { reproducibility }\end{array}$ & $\begin{array}{l}\text { Further studies required, time } \\
\text { consuming, influenced by } \\
\text { smoking, caffeine, diet }\end{array}$ \\
\hline $\begin{array}{l}\text { Late-phase sputum } \\
\text { induction }\end{array}$ & Cell and cytokine profile & Airways inflammation & Non-invasive & $\begin{array}{l}\text { High costs, little evidence, poor } \\
\text { standardisation, unknown } \\
\text { reproducibility }\end{array}$ \\
\hline HRCT & Lung attenuation & $\begin{array}{l}\text { Gas trapping, ventilation } \\
\text { heterogeneity }\end{array}$ & $\begin{array}{l}\text { Non-invasive, } \\
\text { high resolution, } \\
\text { good reproducibility }\end{array}$ & $\begin{array}{l}\text { High costs, exposure to } \\
\text { radiations }\end{array}$ \\
\hline MRI & Lung attenuation & $\begin{array}{l}\text { Gas trapping, ventilation } \\
\text { heterogeneity }\end{array}$ & $\begin{array}{l}\text { Non-invasive, high } \\
\text { resolution, no radiations }\end{array}$ & $\begin{array}{l}\text { Not widely available, complex, } \\
\text { high costs }\end{array}$ \\
\hline Bronchoscopy & $\begin{array}{l}\text { Wedged airway resistance, } \\
\text { transbronchial biopsy, BAL }\end{array}$ & $\begin{array}{l}\text { Airway resistance, } \\
\text { inflammation, remodelling }\end{array}$ & $\begin{array}{l}\text { Direct assessment, } \\
\text { highly informative }\end{array}$ & $\begin{array}{l}\text { Invasive, time consuming, } \\
\text { unknown reproducibility }\end{array}$ \\
\hline \multicolumn{5}{|c|}{$\begin{array}{l}\text { AX: area of reactance; BAL: bronchial alveolar lavage; CalvNO: alveolar concentration of } \mathrm{NO} ; \mathrm{FEF}_{25-75 \%} \text { : forced expiratory flow at } 25-75 \% \text { of forced vital capacity; } \\
\text { FeNO: fractional exhaled nitric oxide; FOT/IOS: forced oscillation technique/impulse oscillometry; FRC: functional residual capacity; FVC: forced vital capacity; HRCT: high } \\
\text { resolution computed tomography; } \mathrm{MBN}_{2} \mathrm{~W} \text { : multiple breath nitrogen washout; } \mathrm{NO} \text { : nitric oxide; R5: airways resistance at } 5 \mathrm{~Hz} \text {; MRI: magnetic resonance imaging; R20: airways } \\
\text { resistance at } 20 \mathrm{~Hz} \text {; RV: residual volume; SAD: small airways disease; } \mathrm{SBN}_{2} \mathrm{~W} \text { : single breath nitrogen washout; Scond, Sacin: multiple breath washout index of conductive } \\
\text { and acinar ventilation heterogeneity; SVC: slow vital capacity; TLC: total lung capacity; X5: reactance at } 5 \mathrm{~Hz} \text {. }\end{array}$} \\
\hline
\end{tabular}

minimum patient cooperation ${ }^{29,30}$. In IOS small amplitude pressure oscillations are applied to the airways by a loudspeaker through a mouthpiece at different frequencies to measure airways impedance, resistance and reactance ${ }^{31}$. The difference between $\mathrm{R} 5$ (resistance at $5 \mathrm{~Hz}$; total airway resistance) and R20 (resistance at $20 \mathrm{~Hz}$; proximal airway resistance) indicates the resistance in the peripheral airways ${ }^{32,33}$.

Imaging techniques by high-resolution computed tomography (HRCT) of the lungs can identify areas of different attenuation in the lung as a result of ventilation heterogeneity caused by SAD (Fig. 2) ${ }^{34}$.

Magnetic resonance imaging (MRI) does not expose the patient to ionising radiation, but it has poor contrast resolution. The requirement of additional enhancement tools makes it difficult to use this technique in clinical practice ${ }^{35,36}$.

To assess the inflammatory pattern of the more peripheral airways, sequential sputum induction 


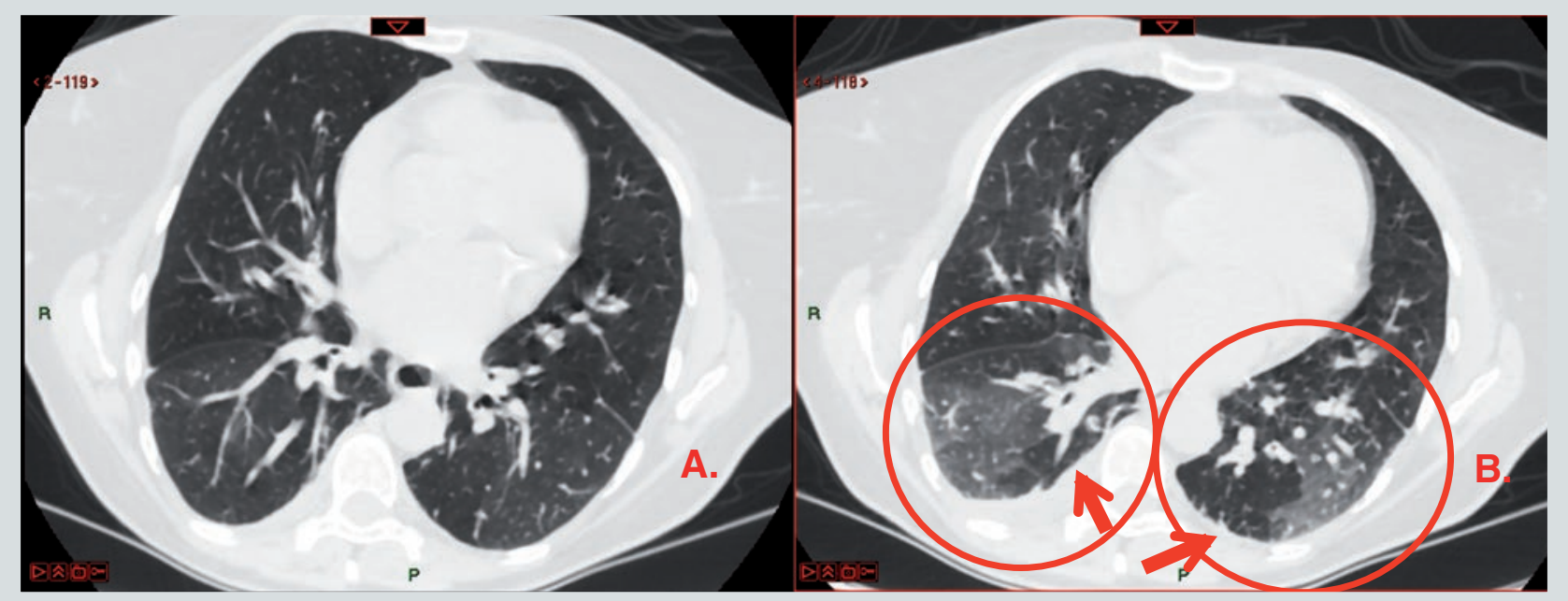

FIgURE 2. HRCT detection of gas trapping. A) Inspiratory CT sequence. B) Expiratory CT sequence (bronchodilators witheld by more than 12 hours) showing low lung attenuation areas (see arrows). CT: computed tomography; HRCT: high resolution computed tomography.

has been investigated, but the available techniques cannot reliably distinguish between different anatomical compartments ${ }^{37,38}$.

Exhaled breath nitric oxide (eNO) is associated with airway inflammation ${ }^{39}$. By using different exhalation flow-rates, it is possible to distinguish NO produced in central airways (low exhalation flows) from NO generated in peripheral regions (high flows); back diffusion of $\mathrm{NO}$ is among the confounding factors of this latter type of assessment ${ }^{40}$.

Recently, the prevalence of small airways dysfunction and alteration in asthma has been thoroughly reviewed for each individual modality of assessment. In table 2, we highlight some of the available data that are particularly informative.

Overall, SAD is present in the majority of the asthmatic population (between $50 \%$ and
$60 \%$ ), irrespective of the degree of severity, with a trend in increased prevalence with severity when imaging (HRCT) and lung function are the tools of assessment ${ }^{52}$.

These data suggest that there is no unique technique or reference gold standard to identify the involvement of the small airways in the asthmatic population. The overall picture of SAD may then derive from the integration of different pieces of information obtained by different techniques (Fig. 3).

Pioneering analyses indicate that different parameters and techniques, when combined, can provide a more efficient instrument for the assessment of $\mathrm{SAD}^{53}$.

However, the tools to detect small airways abnormalities and dysfunction are not always available in everyday clinical practice, and the assessment of SAD is not routinely performed. From a practical viewpoint, some 
TABLE 2. Prevalence of SAD through different diagnostic techniques

\begin{tabular}{|c|c|c|c|c|}
\hline Study & Patients & Tool of assessment & Measures & $\begin{array}{l}\text { Prevalence } \\
\text { of SAD }\end{array}$ \\
\hline Manoharan et al. ${ }^{41}$ & Unselected asthmatic patients ( $n=442$ ) & Spirometry & $\mathrm{FEF}_{25-75}$ & $54 \%$ \\
\hline Jain et al. ${ }^{42}$ & Unselected asthmatic patients ( $n=321$ ) & Plethysmography & $\begin{array}{l}\text { RV } \\
\text { RV/TLC }\end{array}$ & $\begin{array}{l}52 \% \\
57 \%\end{array}$ \\
\hline \multirow[t]{2}{*}{ Perez et al. ${ }^{18}$} & $\begin{array}{l}\text { Clinically stable moderate-to-severe } \\
\text { asthmatic patients without proximal } \\
\text { airways obstruction (normal } \mathrm{FEV}_{1} \text { ) }(\mathrm{n}=222)\end{array}$ & Spirometry, plethysmography & $\mathrm{FRC}, \mathrm{RV}, \mathrm{RV} / \mathrm{TLC}$ & $52 \%$ \\
\hline & $\begin{array}{l}\text { Clinically stable moderate-to-severe } \\
\text { asthmatic patients with proximal airways } \\
\text { obstruction (reduced FEV } \mathrm{FEV}_{1}(\mathrm{n}=219)\end{array}$ & Spirometry, plethysmography & FRC, RV, RV/TLC & $64 \%$ \\
\hline Perez et al. ${ }^{43}$ & $\begin{array}{l}\text { Asthmatic patients with uncontrolled asthma } \\
(\text { ACT }<20)(n=324)\end{array}$ & Spirometry, plethysmography & $\begin{array}{l}\text { FRC } \\
\text { RV }\end{array}$ & $\begin{array}{l}47 \% \\
49 \%\end{array}$ \\
\hline Alfieri et al..$^{44}$ & Mild to moderate asthma $(n=63)$ & Impulse oscillometry & R5-R20 & $48 \%$ \\
\hline Anderson et al. ${ }^{45}$ & $\begin{array}{l}\text { Asthma patients BTS treatment stage } 2 \text { to } 4 \\
(\mathrm{n}=378)\end{array}$ & Impulse oscillometry & R5-R20 & $\begin{array}{l}\text { BTS2 65\% } \\
\text { BTS3 } 64 \% \\
\text { BTS4 } 70 \%\end{array}$ \\
\hline Manoharan et al. ${ }^{41}$ & Unselected asthmatic patients ( $n=442$ ) & Impulse oscillometry & $\mathrm{R} 5-\mathrm{R} 20$ & $42 \%$ \\
\hline Pisi et al..$^{46}$ & Unselected asthmatic patients $(n=33)$ & Impulse oscillometry & R5-R20 & $33 \%$ \\
\hline Gonem et al. ${ }^{47}$ & Asthmatic patients GINA step 3 to 5 & $\begin{array}{l}\text { Multiple breath nitrogen } \\
\text { washout }\end{array}$ & Sacin, Scond & $46 \%$ \\
\hline Hanon et al. ${ }^{48}$ & Stable asthmatic patients $(n=66)$ & $\begin{array}{l}\text { Multiple breath nitrogen } \\
\text { washout }\end{array}$ & Sacin & $53 \%$ \\
\hline Verbanck et al. ${ }^{49}$ & Stable asthmatic patients $(n=33)$ & $\begin{array}{l}\text { Multiple breath nitrogen } \\
\text { washout }\end{array}$ & Sacin & $53 \%$ \\
\hline \multirow[t]{2}{*}{ Thompson et al..$^{50}$} & Exacerbated asthmatic patients $(n=18)$ & \multirow[t]{2}{*}{$\begin{array}{l}\text { Multiple breath nitrogen } \\
\text { washout }\end{array}$} & Sacin & $61 \%$ \\
\hline & Stable asthmatic controls $(n=19)$ & & & $74 \%$ \\
\hline Tunon-de-Lara et al. ${ }^{51}$ & $\begin{array}{l}\text { Uncontrolled mild-to-moderate asthmatics } \\
\qquad(\mathrm{n}=58)\end{array}$ & HRCT & $\begin{array}{l}\text { Gas trapping according } \\
\text { to the definition of the } \\
\text { Fleischner Society }\end{array}$ & $56 \%$ \\
\hline
\end{tabular}

ACT: asthma control test; FEF 25-75\%: forced expiratory flow at 25-75\% of forced vital capacity; BTS: British Thoracic Society; FRC: functional residual capacity; HRCT: high resolution computed tomography; R5: airways resistance at $5 \mathrm{~Hz}$; R20: airways resistance at $20 \mathrm{~Hz}$; RV: residual volume; Sacin: indices of ventilation heterogeneity in the acinar; SAD: small airways disease; Scond: conductive; TLC: total lung capacity.

basic elements have been suggested to identify patients who deserve the assessment of the peripheral district most. These characteristics are summarised in table $3^{52}$.

A large international study currently ongoing, the AssessmenT of smalL Airways involvemeNT In aSthma (ATLANTIS) study, was designed to assess small airways abnormalities by means of all known technologies currently available to investigate the peripheral district and identify clinical expression related to SAD in asthma. The study will also allow comparison and integration of the information obtained by capturing the different aspects of small airways alterations ${ }^{54}$.

\section{CLINICAL IMPACT OF SMALL AIRWAYS DISEASE IN ASTHMA: EVIDENCE AND LINKS}

Asthma control and exacerbation risk reduction are the main goals of asthma management ${ }^{1}$. 

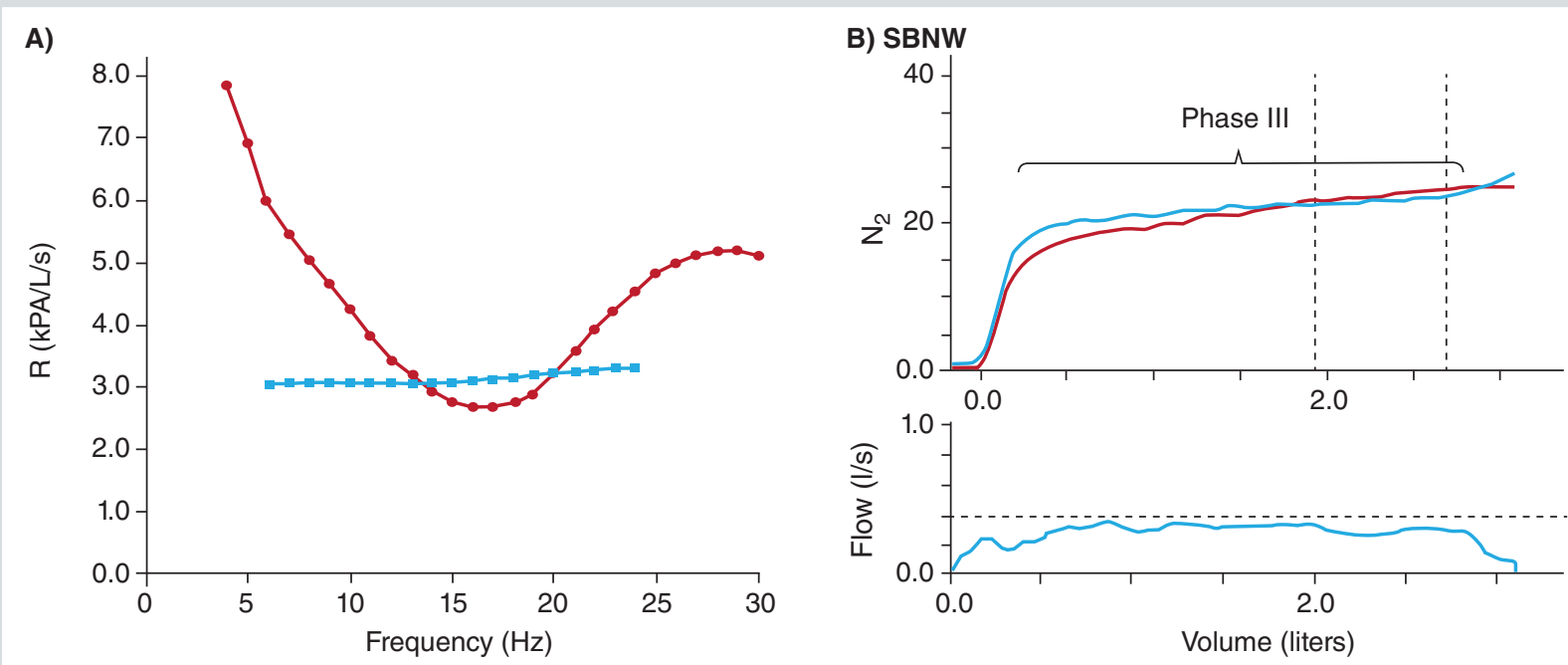

C)
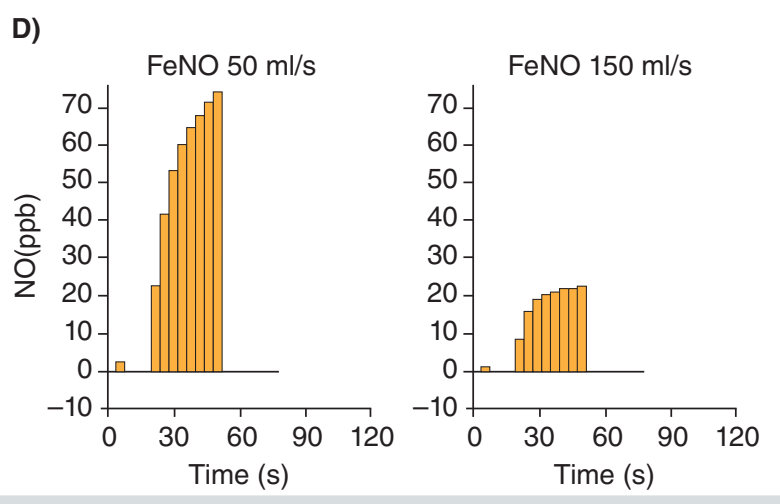

Figure 3. Examples of techniques for assessment of SAD. A) Example of graph obtained by IOS (in our centre in Ferrara) for the resistance study. On the $X$ axis different frequencies of pressure oscillations emitted from the loudspeaker. On $Y$ axes different airways resistance. B) Original example of graph obtained by single breath nitrogen washout (SBNW) test. On X axis lung volume. On $\mathrm{Y}$ axes level on $\mathrm{N}_{2}$ during washout and air flow (the patient attempts to maintain a steady flow of air at $0.5 \mathrm{~L} / \mathrm{sec}$ ). Study of phase III slope is usually used as index of ventilation inhomogeneity. C) Original example of graphs obtained by multiple breath nitrogen washout $\left(\mathrm{MBN}_{2} \mathrm{~W}\right.$ ) test. The course of the $\mathrm{N}_{2}$ washout can be used as a ventilation inhomogeneity index in small airways disease (SAD). On $\mathrm{X}$ axis time (s). On $\mathrm{Y}$ axis $\mathrm{N}_{2}$ concentration and volume of patient tidal breathing (L). D) Original example of graphs obtained by fractional exhaled nitric oxide (FeNO). Levels of eNO at different flow rates can be considered as index of airways inflammation at different levels of the respiratory tree.

ERV: expiratory reserve volume; Meas: measured value, $\mathrm{N}_{2}$ : nitrogen; R: resistance; Ref: reference value: RV: residual volume; TLC: total lung capacity.

TABLE 3. Characteristics of the small airways asthma phenotype

\begin{tabular}{|l|l|}
\hline Symptoms and clinic & $-\mathrm{ACQ}>1.5$ \\
& - Persistent daytime and night-time symptoms \\
\hline Therapy & - Regular use of reliever therapy in response to bronchoconstrictor stimuli or \\
\hline Spirometric and functional features & - A requirement for oral corticosteroids during a viral respiratory infection \\
\hline & $-\mathrm{FEV}_{1}>80 \%$ \\
\hline
\end{tabular}

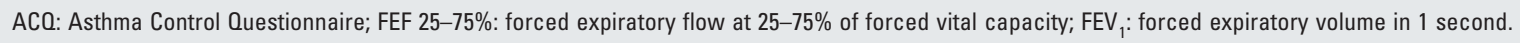


In real-world settings, asthma control is reported in less than $50 \%$ of the asthma population, a value substantially lower than that attainable in randomised controlled trials (RCTs) ${ }^{55}$.

Among the causes of this gap, the inadequate treatment of SAD may contribute to maintaining an unstable inflammatory process and the pathophysiological mechanisms related to the clinical manifestation of the disease ${ }^{56}$.

From a lung function perspective, $\mathrm{FEV}_{1}$ is the parameter most frequently assessed in clinical practice (and in clinical trials), and yet its correlations with asthma symptoms are quite weak, suggesting that other components of the lung pathophysiology could contribute to the clinical expression of the disease and to asthma control $^{57}$.

From early pathology studies, it emerged that the peripheral district is affected by the same inflammatory process typically found in large airways in asthma. Bronchial alveolar lavage (BAL) fluid from asthmatic patients contains a higher number of eosinophils than that of healthy controls. Worse clinical scores have been associated with high eosinophils in BAL fluid, suggesting a correlation between involvement of the small airways and asthma clinical severity ${ }^{58}$.

In a cohort of asthmatic children with documented airflow reversibility, it has been found that children with severe exacerbations had marked gas trapping, identified by increased RV and increased RV/TLC, compared to non-exacerbating children ${ }^{59}$.

In addition, Takeda et al. ${ }^{60}$, by spirometry and IOS assessments in asthmatic patients of different degrees of severity, found a weak correlation among $\mathrm{FEV}_{1}$, health status and dyspnoea, whereas a significant association was found among peripheral airways (as assessed by IOS R5-R20) and health status and dyspnoea.

These data suggest that small airways can contribute, independently from large airways, to the clinical manifestations of asthma.

The involvement of small airways in specific clinical manifestations and outcomes of the disease has also been investigated. In adult asthmatics with preserved lung function, peripheral airways impairment (resulting in lower $\mathrm{FEF}_{25-75}$ and lower R5-R20 values) significantly correlated with a higher risk of poor asthma control ${ }^{61}$.

Similarly, the degree of asthma control (controlled versus uncontrolled) had been efficiently discriminated by IOS (R5-R20 and reactance area values) with a high sensitivity and specificity ( $84 \%$ and $86 \%$, respectively) in asthmatic children ${ }^{33}$.

On the same line, ventilation heterogeneity, assessed by $\mathrm{MBN}_{2} \mathrm{~W}$ or $\mathrm{SBN}_{2} \mathrm{~W}$, has been repeatedly associated with poorly controlled asthma, suggesting that improvement in ventilation heterogeneity could lead to better symptom control $^{57}$.

It has also been reported that high alveolar heterogeneity, by $\mathrm{SBN}_{2} \mathrm{~W}$ testing, associates with both impaired asthma control and increased risk of exacerbations ${ }^{62}$.

These data confirmed the relationship previously described between premature airway closure (air trapping (as assessed by means of $\mathrm{SBN}_{2} \mathrm{~W}$ ) and the risk of exacerbation ${ }^{63}$. 
Thus, evidence is accumulating that small airways impairment is associated with reduced asthma control, increased exacerbations risk and worsening quality of life irrespective of the lung function measured by $\mathrm{FEV}_{1}{ }^{64}$.

What still needs to be clarified is the mechanism(s) by which the dysfunction of the peripheral district affects important asthma clinical outcomes. An interesting hypothesis involves alterations of the surfactant proteins.

Surfactant proteins, which are produced by type II alveolar epithelial cells, significantly contribute to lower superficial tension at the air-liquid surface of the distal airways, thus preventing them to collapse. They have also been linked to innate immune response in the distal airways, especially surfactant proteins A and D (SP-A, SP-D) ${ }^{65,66}$. Impaired production/function as consequence of inflammatory processes in the airways would lead to pathophysiological changes in peripheral airways, such as distal airways collapse and increased gas trapping ${ }^{67}$. Altered levels of surfactant proteins in BAL have been detected after specific airways challenge in asthmatic patients ${ }^{68}$. These data were confirmed in a recent study by Mackay et al. ${ }^{69}$ who found decreased SP-D levels in BAL, but increased levels in serum, from severe asthmatic patients when compared to healthy controls. These authors suggested that higher serum SP-D levels could be due to increased vascular permeability to high molecular weight proteins as consequence of inflammatory process. Interestingly, higher serum surfactant protein D levels have been suggested as a marker of COPD severity of clinical usefulness ${ }^{70}$. Benfante et al. ${ }^{71}$ investigated the relationship between surfactant $\mathrm{D}$ levels and asthma severity along with small airways impairment in 44 asthmatic patients, and found that higher serum levels of surfactant D significantly correlated to more severe disease (as defined by GINA treatment step) and with greater small airways impairment (as measured by IOS). These results, if confirmed in further studies, could broaden therapeutic approaches to asthma in the future.

At present, data from clinical trials with drug/inhaled formulation more effectively reaching the peripheral airways (discussed below) provide indirect evidence of the clinical consequences of improving the pathology and pathophysiology of peripheral airways.

\section{SAD AND CLINICAL PHENOTYPES OF ASTHMA}

Phenotypic characterisation is important to identify groups of patients who share common demographic, clinical and/or pathophysiological characteristics, have similar longterm outcomes and that can benefit from specific treatments to ameliorate the management of their disease ${ }^{1}$.

Several studies in the past several years investigated whether the alterations of the peripheral district led to specific clinical phenotypic expression of the disease, such as nocturnal asthma, asthma in smokers, exercise-induced asthma, asthmatics with fixed airflow obstruction and severe or difficult-to-treat asthma ${ }^{72}$.

The seminal studies in nocturnal asthma conducted on airway specimens obtained from 
bronchial and transbronchial biopsies by Kraft et al. ${ }^{11,73}$ showed that patients with nocturnal symptoms had a more relevant eosinophilic infiltration in the small airways than in the proximal airways, particularly in samples obtained during the night. This was associated with increased peripheral airways resistance assessed during bronchoscopy.

About $30 \%$ of the asthma population is actively exposed to cigarette smoking. These patients experience faster lung function decline $^{74}$, increased frequency of exacerbations ${ }^{75}$, reduced asthma control ${ }^{75,76}$ and a poor response to therapy with inhaled and systemic corticosteroids $\mathrm{s}^{77,78}$.

Tobacco smoking is known to have an impact on peripheral airways ${ }^{79,80}$.

Indeed, in addition to the pathology/pathophysiology related to asthma, cigarette smoke promotes neutrophilic inflammation and airways remodelling in both central and peripheral airways ${ }^{81,83}$.

By single-breath nitrogen washout test (SBNT), the phase III slope $\left(\mathrm{dN}_{2}\right)$ was found to be significantly higher in asthmatic smokers, indicating increased ventilation heterogeneity in the small airways of smokers with asthma. This has been confirmed by IOS showing increased small but not large airways resistance in smokers with mild-to-moderate asthma ${ }^{84}$.

In mild and mild intermittent asthma, IOS performed after exercise testing showed greater impairment of small airways in patients with airways hyperresponsiveness (AHR) when compared with asthmatics without AHR, suggesting a role of small airways obstruction in the pathogenesis of exercise-induced bronchoconstriction ${ }^{85}$.

Recent studies investigated the relationship between SAD and bronchial hyperresponsiveness. The results suggest that $S A D$, detected by different techniques is positively associated with BHR independently of $\mathrm{FEV}_{1}^{86,87}$ and that SAD is associated with dyspnoea during such BHR testing ${ }^{87}$.

The duration of the disease is one of the conditions reported to contribute to the development of asthma phenotype with fixed airflow limitation. It involves pathophysiological changes in the peripheral airways (degeneration of elastic fibres with loss of support to airways) increasing their collapsibility and premature closure, thus resulting in increased gas trapping ${ }^{88-92}$.

Interestingly, there is a correlation between small airway abnormalities, as defined by air trapping (increased RV/TLC ratio), and duration of the disease that might be relevant in the development of the fixed airflow limitation asthma phenotype ${ }^{93}$.

However, the exact relationship between SAD and fixed airflow obstruction is still debatable and requires ad hoc studies to be clarified.

It has been proposed to group all the clinical conditions above described under the term of "small airways phenotype" in recognition of the documented impairment of the peripheral district in these clinical conditions, as resumed in figure 4 . This would include a group of patients whose clinical manifestations could be ascribed, at least in part, to a substantial impairment of the peripheral district and who would benefit most from treatments efficiently targeting peripheral airways ${ }^{52,94}$. 


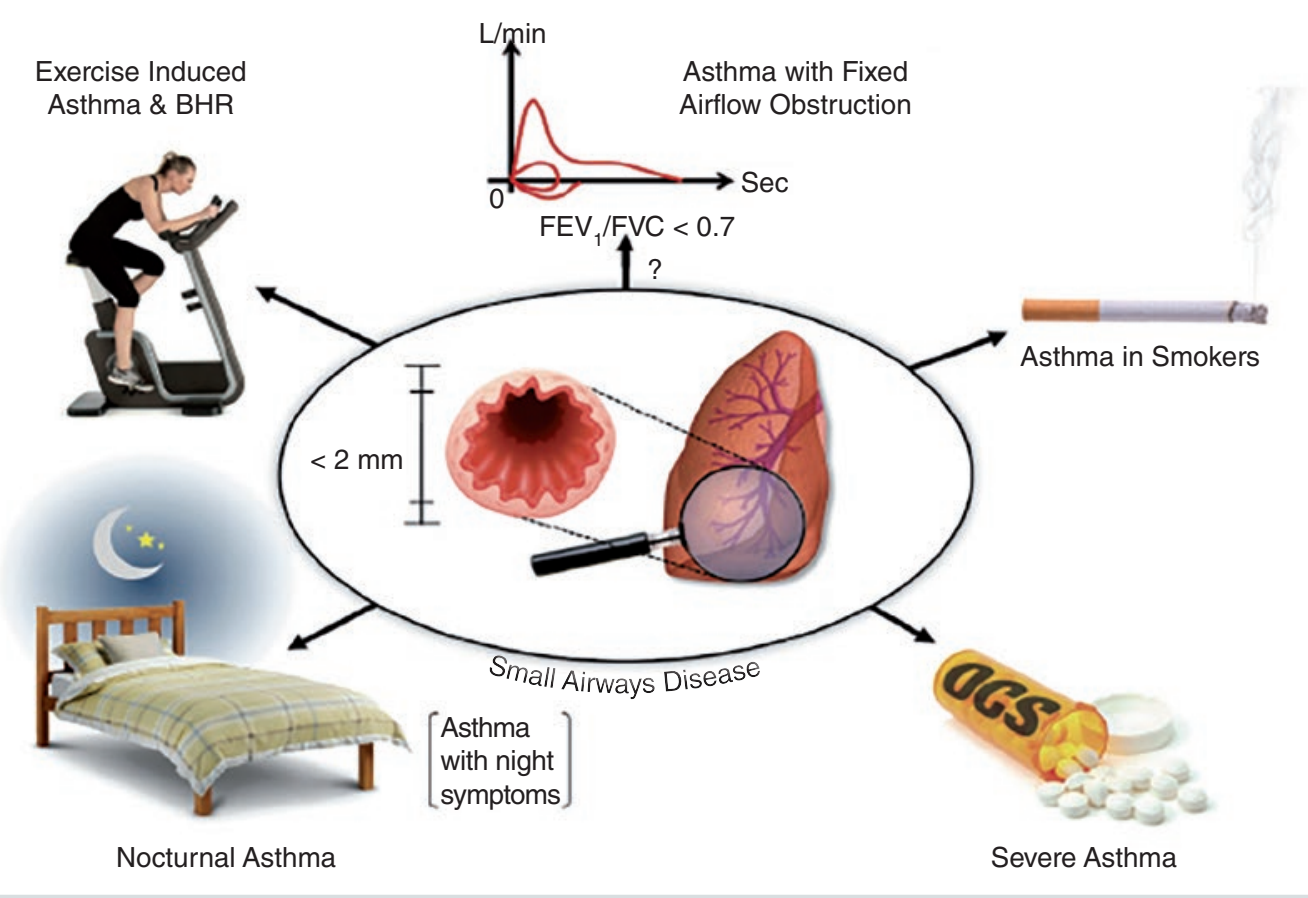

FigURE 4. Small airways disease and asthma phenotypes.

BHR: bronchial hyperresposiveness; FEV $_{1}$ : forced expiratory volume in 1 second; FVC: forced vital capacity; OCS: oral corticosteroids.

\section{SAD IN SEVERE ASTHMA}

Patients with severe asthma represent a minority (5 to $10 \%$ ) of the asthmatic population, but they have a disproportionate impact on health care usage, contributing to the majority of the overall costs of asthma management ${ }^{95}$.

Severe asthma is defined as asthma that requires treatment with high-dose inhaled corticosteroids (ICS) plus a second controller and/or oral corticosteroids to prevent it from becoming uncontrolled, or that remains uncontrolled despite this treatment ${ }^{96}$.

In recent years, several studies have been conducted to investigate the involvement and contribution of small airways in the pathogenesis of these severe clinical conditions. Overall, there is evidence of increased small airway dysfunction in severe versus mild to moderate asthmatic patients ${ }^{97}$.

The enhanced small airway dysfunction could hamper the penetration and deposition of the inhaled treatments leaving undertreated, thus uncontrolled, the peripheral airways inflammation and its pathophysiological and clinical consequences.

Indeed, in specimens from patients who died from severe asthma exacerbation, massive inflammation and structural abnormalities of peripheral airways have been described ${ }^{98-100}$. 
An unanswered question remains, whether such alterations reflected the severity of the acute phase or whether they were related to the severity of the underlying disease.

Some indirect evaluations of inflammation in peripheral airways, assessed by alveolar NO, report higher values in refractory asthma compared to mild-moderate conditions, suggesting a more pronounced inflammatory process in the small airways of severe asth$\mathrm{ma}^{101}$, in line with available evidence in central airways ${ }^{102}$.

Using IOS, the prevalence of SAD has been reported to be as high as 70\% in severely asthmatic subjects ${ }^{45}$.

The European Network for Understanding the Mechanisms of Severe Asthma (ENFUMOSA) Study network completed a multicentre prospective study comparing severe and mild asthmatic patients. By means of non-invasive techniques, reduced FVC and increased RV and $\mathrm{RV} / \mathrm{TLC}$ ratios have been reported in severe asthma, indicating increased gas trapping and small airways dysfunction ${ }^{103}$, in line with other studies of severe asthma ${ }^{22}$.

Similarly, the Severe Asthma Research Programme (SARP) showed a significant reduction in FVC mean value in severe asthmatics when compared to mildly and moderately asthmatic patients ${ }^{104}$.

Of particular interest are the results of a study by in't Veen et al. ${ }^{63}$ in severe asthmatic patients, were frequent vs. infrequent exacerbators were compared. Using the $\mathrm{SBN}_{2} \mathrm{~W}$ test, they found increased $\mathrm{CC}$ and $\mathrm{CV}$ values in frequent exacerbators.
These data suggest the involvement of SAD in specific clinical expression of asthma severity, in particular a greater susceptibility to exacerbations.

The mechanisms that make severe-asthma patients with peripheral airways dysfunction more prone to exacerbations are unknown. It has been proposed that the peripheral partition of the airways is the most difficult to reach by inhalation therapy; thus, it remains relatively undertreated and more responsive to destabilising triggers.

It is likely that small airways dysfunction, although highly prevalent among severely asthmatic subjects, is not equally relevant in the pathophysiology of the different severe-asthma phenotypes.

\section{ASTHMA TREATMENT: TARGETING SAD}

Inhaled treatment is the preferred route of administration of asthma therapy ${ }^{1}$.

In a seminal study, Usmani et al. ${ }^{105}$, using lung scintigraphy, found that large particles $(6 \mu \mathrm{m}$ and $3 \mu \mathrm{m}$ median mass aerodynamic diameter [MMAD]) have a greater deposition in proximal airways than smaller particles $(1.5 \mu \mathrm{m})$, wich preferentially deposit in distal lung regions.

The smaller the size of inhaled particles, the greater is the penetration index. Small particle formulations provide lower oropharyngeal deposition that is related to both local and systemic side effects. Inhaled formulations with a high proportion of fine particle fraction (FPF), or respirable fraction (particles $<5$ microns in aerodynamic diameter) have greater lung deposition ${ }^{106}$. 
Iwanaga et al. ${ }^{107}$ compared drug deposition of different inhaled treatments in the lungs, in mild to moderate persistent asthma, by using functional respiratory imaging, a computational fluid-dynamics-based CT elaboration. Inhaled treatment with high FPF resulted in greater lung deposition ${ }^{107}$.

For environmental reasons, old chlorofluorocarbon (CFC) propellants have been banned and replaced by new hydrofluoroalkane (HFA) propellants. HFAs allowed the development of small particle size formulations. These formulations are available for ICS and fixed ICS/long-acting $\beta_{2}$ agonists (LABAs) combinations ${ }^{23}$.

Their efficacy has been tested in both RCTs and in real-life studies, providing some evidence of the pathophysiological and clinical changes occurring when the peripheral district is more effectively targeted and drug deposition is higher in the peripheral airways.

\section{PATHOPHYSIOLOGICAL AND CLINICAL OUTCOMES RELATED TO SMALL AIRWAYS: INHALED CORTICOSTEROIDS}

Corticosteroid treatment represents the mainstay of asthma management. Several studies have assessed ICS small-particle/extra-fine formulations for pathophysiological and clinical outcomes.

Hauber et al. ${ }^{108}$ investigated the effects of extra-fine HFA-beclomethasone dipropionate (BDP) versus large-particle dry powder inhaler (DPI)-budesonide on early- and late-phase sputum samples in patients with mild asthma. Although both treatments reduced sputum eosinophils and IL-4 and IL-5 mRNA expression in the early-phase sputum samples, only small-particle HFA-BDP reduced these markers in the late-phase samples that better reflect peripheral airway inflammation.

On lung function, ICS extra-fine formulation showed higher potency compared to a non-extra-fine formulation; Busse et al. ${ }^{109}$ reported extra-fine BDP to be equipotent to a 2.6-times higher dose of CFC-BDP in improving $\mathrm{FEV}_{1}$ and asthma control (daytime and night-time symptoms and use of reliever medication).

In the same line, by IOS, a greater reduction in peripheral airway resistance was found in asthmatic patients receiving HFA-BDP compared to a higher (double) CFC-BDP dose. Interestingly this difference was not observed on $\mathrm{FEV}_{1}{ }^{110}$.

In terms of quality of life, Juniper et al. showed greater improvement in the Asthma Quality of Life Questionnaire (AQLQ) in patients switched from CFC-BDP to half-dose extra-fine HFABDP, confirming the increased efficacy of these formulations, better reaching the small airways, on clinical outcomes ${ }^{111}$.

Finally, imaging by HRCT confirmed the effects of extra-fine formulations on the peripheral district, showing a greater improvement in air trapping of extra-fine HFA-BDP compared to conventional CFC-BDP ${ }^{112}$. This provides a static picture of the peripheral changes induced by small particle formulations associated with lung function and clinical outcomes previously described.

Similar data on lung function $\left(\mathrm{FEV}_{1}\right)$ IOS, imaging, peripheral $\mathrm{NO}$ and asthma control 
have been documented when extra-fine ciclesonide was investigated ${ }^{113-115}$.

\section{FIXED COMBINATION ICS/LABA: PATHOPHYSIOLOGICAL AND CLINICAL OUTCOMES RELATED TO SMALL AIRWAYS}

In line with what previously has been described for ICSs, small particle ICS/LABA combinations positively affect small airways function and clinical outcomes.

Scichilone et al. ${ }^{116}$, using an $\mathrm{SBN}_{2} \mathrm{~W}$ test, reported that the extra-fine BDP/Formoterol Fumarate (FF) combination improves both large and small airways function by reducing BHR and closing capacity than treatment with large particle ICS/LABA.

Interestingly, in a study conducted on patients with different degrees of asthma severity switched from previous treatment (either SABA, or ICS, ICS/LABA combinations) to extra-fine pMDI-BDP/formoterol, Vos et al. ${ }^{117}$ observed significant improvements in lung function $\left(\mathrm{FEV}_{1}\right)$, airway inflammation $(\mathrm{eNO})$, and gas trapping (HRCT) in association with benefits in clinical outcomes such as asthma control test (ACT score) ${ }^{117}$.

ICS/LABA extra-fine formulations have been reported to be associated with an overall reduction in ICS dose and a good tolerability profile. Huchon et al. ${ }^{118}$ assessed the clinical efficacy of extra-fine HFA-BDP/formoterol and of a 2.5 times higher dose of pMDI CFCBDP non-extra-fine plus DPI formoterol. The study showed similar improvement in lung function by the two ICS/LABA combinations compared to high-dose BDP non-extra-fine and a higher level of asthma control and lower exacerbation risk with the extra-fine combination. In terms of safety, serum cortisol levels remained within the range of normality, given the lower doses of ICS that patients with extra-fine therapy were exposed to.

Small particle of ICS/LABA combinations have been tested in particular subgroups of asthmatic patients with small airways impairment. A recent study by Contoli et al. ${ }^{84}$ reported that extra-fine $\mathrm{BDP} /$ formoterol $(\mathrm{F})$ improves small airways-related parameters (dN2 measured by $\mathrm{SBN}_{2} \mathrm{~W}$ and R5-R20 measured by IOS) and the degree of asthma control in smoking asthmatic patients more effectively than in non-smoking asthmatic patients.

These studies highlight the importance of tailoring small-particle inhaled treatment in patients with more pronounced involvement in small airways.

\section{SMALL PARTICLE FORMULATIONS AND REAL-LIFE STUDIES}

At variance with $\mathrm{RCT}$, real-life studies are closely associated with routine clinical practice. Indeed, they address clinical outcomes in an unselected asthma population and in clinical settings representing everyday clinical practice $^{119}$.

A meta-analysis recently completed reviewed the effectiveness of extra-fine ICS versus small-particle ICS (either alone or with in association with LABA) in real-life studies of asth$\mathrm{ma}$. The results indicate that the use of extra-fine formulation in real-life settings is associated with higher levels of asthma control, lower ex- 
acerbation rates and lower exposure to $\mathrm{ICS}^{120}$.

Müller et al. ${ }^{121}$, comparing outpatients cross-sectionally with moderate to severe persistent asthma treated with fixed combinations of ICS/LABA, reported that the proportion of patients achieving asthma control was significantly higher in the extra-fine than in the non-extrafine combinations. Notably, this was associated with a lower ICS mean daily dose.

An observational study conducted in the United Kingdom of asthmatic patients previously treated with large-particle ICS/LABA combinations that were prescribed extra-fine $\mathrm{BDP} / \mathrm{F}$ showed a better level of asthma control and lower use of rescue medication with the latter treatment ${ }^{122}$.

Their results were confirmed in other longitudinal studies showing improvement in health-related quality-of-life status with small-particle therapy ${ }^{123,124}$.

In a real-life study, patients prescribed inhaled treatment with high respirable fraction particles showed improved clinical outcomes and low exacerbation rates ${ }^{125}$.

A recent real-life study by Marth et al. ${ }^{126}$ analysed the effects of treatment with extra-fine ICS/ LABA in asthma patients considered more likely to have pronounced impairment of small airways (e.g., smoking asthmatics, patients with signs of gas trapping). The switch from previous treatment to extra-fine $\mathrm{BDP} / \mathrm{F}$ treatment resulted in improved symptoms, reduced use of rescue medication and better asthma control and lung function ( $\mathrm{FEV}_{1}, \mathrm{PEF}$ and FVC) in the overall population and among subgroups of patients identified as having the small airway phenotype ${ }^{126}$.

\section{CONCLUSIONS}

In the past several years, much interest has emerged in a relatively overlooked airways compartment: the small airways. SAD is very common among asthmatics, regardless of the severity of airflow obstruction and severity of the disease. SAD seems particularly pronounced in some specific phenotypes and in severe asthma. Data from pharmacological studies seem indirectly to support the hypothesis that therapies targeting the distal airways can positively influence asthma clinical outcome, particularly among patients with more pronounced small airways involvement. Many aspects however remain unclear, such as the mechanisms by which small airways impairment would affect clinical asthma features. In addition, most of the data have been obtained in small, single-centre studies. However, large real-life studies seem to support the conclusions obtained in strictly controlled conditions.

\section{AKNOWLEDGMENTS}

The Authors thank Marianna Padovani MD, Cindy Rocchi MD and Sara Soave MD for literature and manuscript revision, and Paolo Casolari for providing the small airways picture.

The Authors thank Elisa Veratelli for manuscript editing.

\section{CONFLICT OF INTEREST}

Dr. Alberto Papi reports grants, personal fees, non-financial support and other from Chiesi, grants, personal fees, non-financial support and other from Astrazeneca, grants, personal fees, 
non-financial support and other from GlaxoSmithKline, grants, personal fees, non-financial support and other from Boehringer Ingelheim, personal fees and non-financial support from Menarini, personal fees and non-financial support from Novartis, personal fees and non-financial support from Zambon, grants, personal fees, non-financial support and other from Pfizer, grants, personal fees, non-financial support and other from Mundipharma, grants, personal fees, non-financial support and other from TEVA, grants from Sanofi, outside the submitted work, Dr. Federico Bellini and Dr. Luca Morandi have nothing to disclose.

\section{REFERENCES}

1. Global Initiative for Asthma. Global Strategy for Asthma Management and Prevention 2017. Available from: www.ginasthma.org.

2. Haldar P, Pavord ID, Shaw DE et al. Cluster analysis and clinical asthma phenotypes. Am J Respir Crit Care Med. 2008;178:218-24.

3. Moore WC, Meyers DA et al. Identification of asthma phenotypes using cluster analysis in the Severe Asthma Research Program. Am J Respir Crit Care Med. 2010;181:315-23.

4. Macklem PT, Mead J. Resistance of central and peripheral airways measured by a retrograde catheter. J Appl Physiol. 1967;22:395-401.

5. Mead J. The lung's “quiet zone." N Engl J Med. 1970;282:1318-9.

6. Virchow JC. [Asthma--a small airway disease: concepts and evidence]. Pneumol Stuttg Ger. 2009;63 Suppl 2:S96-101.

7. Hamid Q, Song Y, Kotsimbos TC et al. Inflammation of small airways in asthma. J Allergy Clin Immunol. 1997;100:44-51.

8. Saetta M, Di Stefano A, Rosina C, Thiene G, Fabbri LM. Quantitative structural analysis of peripheral airways and arteries in sudden fatal asthma. Am Rev Respir Dis. 1991; 143:138-43.

9. van den Berge M, Ten Hacken NHT, Cohen J, Douma WR, Postma DS. Small airway disease in asthma and COPD: clinical implications. Chest. 2011;139:412-23.

10. Carroll N, Elliot J, Morton A, James A. The structure of large and small airways in nonfatal and fatal asthma. Am Rev Respir Dis. 1993;147:405-10.

11. Kraft M, Djukanovic R, Wilson S, Holgate ST, Martin RJ. Alveolar tissue inflammation in asthma. Am J Respir Crit Care Med. 1996;154:1505-10.

12. Wenzel SE, Szefler SJ, Leung DY, Sloan SI, Rex MD, Martin RJ. Bronchoscopic evaluation of severe asthma. Persistent inflammation associated with high dose glucocorticoids. Am J Respir Crit Care Med. 1997;156:737-43.

13. Wagner EM, Bleecker ER, Permutt S, Liu MC. Direct assessment of small airways reactivity in human subjects. Am J Respir Crit Care Med. 1998;157: 447-52.

14. Yanai M, Sekizawa K, Ohrui T, Sasaki H, Takishima T. Site of airway obstruction in pulmonary disease: direct measurement of intrabronchial pressure. J Appl Physiol (1985). 1992;72:1016-23.

15. Wagner PD, Dantzker DR, Iacovoni VE, Tomlin WC, West JB. Ventilation-perfusion inequality in asymptomatic asthma. Am Rev Respir Dis. 1978;118:511-24.
16. Young IH, Corte P, Schoeffel RE. Pattern and time course of ventilation-perfusion inequality in exercise-induced asthma. Am Rev Respir Dis. 1982; 125:304-11.

17. Wagner PD, Hedenstierna G, Rodriguez-Roisin R. Gas exchange, expiratory flow obstruction and the clinical spectrum of asthma. Eur Respir J. 1996;9:1278-82.

18. Perez T, Chanez P, Dusser D, Devillier P. Small airway impairment in moderate to severe asthmatics without significant proximal airway obstruction. Respir Med. 2013; 107:1667-74.

19. Stănescu D. Small airways obstruction syndrome. Chest. 1999; 116:231-3.

20. Timmins SC, Diba C, Farrow CE et al. The relationship between airflow obstruction, emphysema extent, and small airways function in COPD. Chest. 2012;142:312-9.

21. Pellegrino R, Viegi G, Brusasco V et al. Interpretative strategies for lung function tests. Eur Respir J. 2005;26:948-68.

22. Sorkness RL, Bleecker ER, Busse WW et al. Lung function in adults with stable but severe asthma: air trapping and incomplete reversal of obstruction with bronchodilation. J Appl Physiol (1985). 2008; 104:394-403.

23. Scichilone N, Battaglia S, Olivieri D, Bellia V. The role of small airways in monitoring the response to asthma treatment: what is beyond FEV1? Allergy. 2009;64:1563-9.

24. Lung function testing: selection of reference values and interpretative strategies. American Thoracic Society. Am Rev Respir Dis. 1991; 144:1202-18.

25. Drummond GB, Milic-Emili J. Forty years of closing volume. Br J Anaesth 2007; 99:772-4.

26. Downie SR, Salome CM, Verbanck S, Thompson B, Berend N, King GG Ventilation heterogeneity is a major determinant of airway hyperresponsiveness in asthma, independent of airway inflammation. Thorax. 2007 62:684-9.

27. Crawford AB, Makowska M, Paiva M, Engel LA. Convection- and diffusion-dependent ventilation maldistribution in normal subjects. J Appl Physiol (1985). 1985;59:838-46.

28. Verbanck S, Schuermans D, Noppen M, Van Muylem A, Paiva M, Vincken W. Evidence of acinar airway involvement in asthma. Am J Respir Crit Care Med. 1999;159:1545-50.

29. Dubois AB, Brody AW, Lewis DH, Burgess BF. Oscillation mechanics of lungs and chest in man. J Appl Physiol. 1956;8:587-94.

30. Oostveen E, MacLeod D, Lorino $\mathrm{H}$ et al. The forced oscillation technique in clinical practice: methodology, recommendations and future developments. Eur Respir J. 2003;22:1026-41.

31. Goldman MD, Saadeh C, Ross D. Clinical applications of forced oscillation to assess peripheral airway function. Respir Physiol Neurobiol. 2005;148: 179-94.

32. Verbanck S. Physiological measurement of the small airways. Respir Int Rev Thorac Dis. 2012;84:177-88.

33. Shi Y, Aledia AS, Tatavoosian AV, Vijayalakshmi S, Galant SP, George SC. Relating small airways to asthma control by using impulse oscillometry in children. J Allergy Clin Immunol. 2012;129:671-8.

34. Gupta S, Raj V, Castro M. Imaging in severe asthma. In: Chung KF, Bel EH, and Wenzel SE, editors. Difficult-to-treat Severe asthma. ; 2011;160-72. (ERS Monograph; vol. 12).

35. Burgel PR. The role of small airways in obstructive airway diseases. Eur Respir Rev. 2011;20:23-33.

36. Burgel PR, de Blic J, Chanez P et al. Update on the roles of distal airways in asthma. Eur Respir Rev. 2009;18:80-95.

37. Gershman NH, Liu H, Wong HH, Liu JT, Fahy JV. Fractional analysis of sequential induced sputum samples during sputum induction: evidence that different lung compartments are sampled at different time points. Allergy Clin Immunol. 1999;104:322-8.

38. Richter K, Holz O, Jörres RA, Mücke M, Magnussen H. Sequentially induced sputum in patients with asthma or chronic obstructive pulmonary disease. Eur Respir J. 1999;14:697-701.

39. Barnes PJ, Dweik RA, Gelb AF et al. Exhaled nitric oxide in pulmonary diseases: a comprehensive review. Chest. 2010.138:682-92. 
40. Van Muylem A, Kerckx Y, Michils A. Acinar effect of inhaled steroids evidenced by exhaled nitric oxide. J Allergy Clin Immunol. 2010;126:730-735.e2.

41. Manoharan A, Anderson WJ, Lipworth J, Lipworth BJ. Assessment of spirometry and impulse oscillometry in relation to asthma control. Lung. 2015;193:47-51.

42. Jain VV, Abejie B, Bashir MH, Tyner T, Vempilly J. Lung volume abnormalities and its correlation to spirometric and demographic variables in adult asthma. J Asthma. 2013;50:600-5.

43. Perez T, Chanez P, Dusser D, Devillier P. Prevalence and reversibility of lung hyperinflation in adult asthmatics with poorly controlled disease or significant dyspnea. Allergy. 2016;71:108-14.

44. Alfieri V, Aiello M, Pisi R et al. Small airway dysfunction is associated to excessive bronchoconstriction in asthmatic patients. Respir Res. 2014; 27;15:86.

45. Anderson WJ, Zajda E, Lipworth BJ. Are we overlooking persistent small airways dysfunction in community-managed asthma? Ann Allergy Asthma Immunol. 2012;109:185-189.e2.

46. Pisi R, Tzani P, Aiello M et al. Small airway dysfunction by impulse oscillometry in asthmatic patients with normal forced expiratory volume in the 1st second values. Allergy Asthma Proc. 2013;34:e14-20.

47. Gonem S, Hardy S, Buhl N et al. Characterization of acinar airspace involvement in asthmatic patients by using inert gas washout and hyperpolarized (3)helium magnetic resonance. J Allergy Clin Immunol. 2016;137: 417-25.

48. Hanon S, Schuermans D, Vincken W, Verbanck S. Irreversible acinar airway abnormality in well controlled asthma. Respir Med. 2014;108:1601-7.

49. Verbanck S, Schuermans D, Paiva M, Vincken W. The functional benefit of anti-inflammatory aerosols in the lung periphery. J Allergy Clin Immunol. 2006;118:340-6.

50. Thompson BR, Douglass JA, Ellis MJ et al. Peripheral lung function in patients with stable and unstable asthma. J Allergy Clin Immunol. 2013; 131:1322-8

51. Tunon-de-Lara J-M, Laurent F, Giraud V et al. Air trapping in mild and moderate asthma: effect of inhaled corticosteroids. J Allergy Clin Immunol. 2007;119:583-90.

52. Lipworth B, Manoharan A, Anderson W. Unlocking the quiet zone: the small airway asthma phenotype. Lancet Respir Med. 2014;2:497-506.

53. Usmani OS, Singh D, Spinola M, Bizzi A, Barnes PJ. The prevalence of small airways disease in adult asthma: A systematic literature review. Respir Med. 2016;116:19-27.

54. Postma DS, Brightling C, Fabbri L et al. Unmet needs for the assessment of small airways dysfunction in asthma: introduction to the ATLANTIS study. Eur Respir J. 2015;45:1534-8.

55. Demoly P, Annunziata K, Gubba E, Adamek L. Repeated cross-sectional survey of patient-reported asthma control in Europe in the past 5 years. Eur Respir Rev. 2012;21:66-74.

56. Haughney J, Price D, Kaplan A et al. Achieving asthma control in practice: understanding the reasons for poor control. Respir Med. 2008.102:1681-93.

57. Farah CS, King GG, Brown NJ et al. The role of the small airways in the clinical expression of asthma in adults. J Allergy Clin Immunol. 2012;129: 381-387, 387.e1.

58. Vyve TV, Chanez P, Lacoste J-Y, Bousquet J, Michel F-B, Godard P. Comparison between Bronchial and Alveolar Samples of Bronchoalveolar Lavage Fluid in Asthma. CHEST. 1992;;102:356-61.

59. Mahut B, Peiffer C, Bokov P, Beydon N, Delclaux C. Gas trapping is associated with severe exacerbation in asthmatic children. Respir Med. 2010; 104:1230-3.

60. Takeda T, Oga T, Niimi A et al. Relationship between small airway function and health status, dyspnea and disease control in asthma. Respir Int Rev Thorac Dis. 2010;80:120-6.

61. Manoharan A, Anderson WJ, Lipworth J, Ibrahim I, Lipworth BJ. Small airway dysfunction is associated with poorer asthma control. Eur Respir J. 2014;;44:1353-5.

62. Bourdin A, Paganin F, Préfaut C, Kieseler D, Godard P, Chanez P. Nitrogen washout slope in poorly controlled asthma. Allergy. 2006;61:85-9.
63. in 't Veen JC, Beekman AJ, Bel EH, Sterk PJ. Recurrent exacerbations in severe asthma are associated with enhanced airway closure during stable episodes. Am J Respir Crit Care Med. 2000;161:1902-6.

64. Cottini M, Lombardi C, Micheletto C. Small airway dysfunction and bronchial asthma control : the state of the art. Asthma Res Pract. 2015;1:13.

65. Griese M. Pulmonary surfactant in health and human lung diseases: state of the art. Eur Respir J. 1999;13:1455-76.

66. Forbes LR, Haczku A. SP-D and regulation of the pulmonary innate immune system in allergic airway changes. Clin Exp Allergy. 2010;40:547-62.

67. Hohlfeld JM. The role of surfactant in asthma. Respir Res. 2002;3:4.

68. Erpenbeck VJ, Schmidt R, Günther A, Krug N, Hohlfeld JM. Surfactant protein levels in bronchoalveolar lavage after segmental allergen challenge in patients with asthma. Allergy. 2006;61:598-604.

69. Mackay R-MA, Grainge CL, Lau LC, Barber C, Clark HW, Howarth PH Airway Surfactant Protein D Deficiency in Adults With Severe Asthma. Chest. 2016;149:1165-72.

70. Sin DD, Man SFP, Marciniuk DD et al. The effects of fluticasone with or without salmeterol on systemic biomarkers of inflammation in chronic obstructive pulmonary disease. Am J Respir Crit Care Med. 2008;177:1207-14.

71. Benfante A, Battaglia S, Principe S et al. Asthmatics with high levels of serum surfactant protein D have more severe disease. Eur Respir J. 2016;47: 1864-7.

72. Bjermer L. The role of small airway disease in asthma. Curr Opin Pulm Med. 2014;20:23-30.

73. Kraft M, Pak J, Martin RJ, Kaminsky D, Irvin CG. Distal Lung Dysfunction at Night in Nocturnal Asthma. Am J Respir Crit Care Med. 2001;163:1551-6.

74. Lange P, Parner J, Vestbo J, Schnohr P, Jensen G. A 15-year follow-up study of ventilatory function in adults with asthma. N Engl J Med. 1998;339:1194-200.

75. Pedersen SE, Bateman ED, Bousquet J et al. Determinants of response to fluticasone propionate and salmeterol/fluticasone propionate combination in the Gaining Optimal Asthma controL study. J Allergy Clin Immunol 2007;120:1036-42.

76. Chapman KR, Boulet LP, Rea RM, Franssen E. Suboptimal asthma control prevalence, detection and consequences in general practice. Eur Respir J 2008;31:320-5.

77. Chalmers GW, Macleod KJ, Little SA, Thomson LJ, McSharry CP, Thomson NC. Influence of cigarette smoking on inhaled corticosteroid treatment in mild asthma. Thorax. 2002;57:226-30.

78. Barnes PJ. Corticosteroid resistance in patients with asthma and chronic obstructive pulmonary disease. J Allergy Clin Immunol. 2013;131:636-45.

79. Cosio M, Ghezzo H, Hogg JC et al. The relations between structural changes in small airways and pulmonary-function tests. N Engl J Med. 1978;298: 1277-81.

80. Niewoehner DE, Kleinerman J, Rice DB. Pathologic changes in the peripheral airways of young cigarette smokers. N Engl J Med. 1974;291:755-8.

81. Boulet L-P, Lemière C, Archambault F, Carrier G, Descary MC, Deschesnes F. Smoking and asthma: clinical and radiologic features, lung function, and airway inflammation. Chest. 2006;129:661-8.

82. Livingston E, Chaudhuri R, McMahon AD, Fraser I, McSharry CP, Thomson NC. Systemic sensitivity to corticosteroids in smokers with asthma. Eur Respir J. 2007;29:64-71.

83. Broekema M, ten Hacken NHT, Volbeda F et al. Airway epithelial changes in smokers but not in ex-smokers with asthma. Am J Respir Crit Care Med. 2009;180:1170-8.

84. Contoli M, Bellini F, Morandi L et al. Assessing small airway impairment in mild-to-moderate smoking asthmatic patients. Eur Respir J. 2016;47:1264-7.

85. Lee JH, Lee YW, Shin YS, Jung YH, Hong CS, Park JW. Exercise-induced airway obstruction in young asthmatics measured by impulse oscillometry. J Investig Allergol Clin Immunol. 2010;20:575-81.

86. Telenga ED, van den Berge M, Ten Hacken NHT, Riemersma RA, van der Molen T, Postma DS. Small airways in asthma: their independent contribution to the severity of hyperresponsiveness. Eur Respir J. 2013;41:752-4.

87. van der Wiel E, Postma DS, van der Molen T, Schiphof-Godart L, Ten Hacken NHT, van den Berge M. Effects of small airway dysfunction on the clinical expression of asthma: a focus on asthma symptoms and bronchial hyper-responsiveness. Allergy. 2014;69:1681-8. 
88. Bellia V, Cibella F, Cuttitta G et al. Effect of age upon airway obstruction and reversibility in adult patients with asthma. Chest. 1998;114:1336-42.

89. Kizkin O, Turker G, Hacievliyagil SS, Gunen H. Asthma, age, and early reversibility testing. J Asthma. 2003;40:317-21.

90. Contoli M, Baraldo S, Marku B et al. Fixed airflow obstruction due to asthma or chronic obstructive pulmonary disease: 5-year follow-up. J Allergy Clin Immunol. 2010;125:830-7.

91. Verbeken EK, Cauberghs M, Mertens I, Clement J, Lauweryns JM, Van de Woestijne KP. The senile lung. Comparison with normal and emphysematous lungs. 1. Structural aspects. Chest. 1992;101:793-9.

92. Verbeken EK, Cauberghs M, Mertens I, Clement J, Lauweryns JM, Van de Woestijne KP. The senile lung. Comparison with normal and emphysematous lungs. 2. Functional aspects. Chest. 1992;101:800-9.

93. Cassino C, Berger KI, Goldring RM et al. Duration of Asthma and Physiologic Outcomes in Elderly Nonsmokers. Am J Respir Crit Care Med. 2000; $162: 1423-8$

94. Proceedings of the ATS workshop on refractory asthma: current understanding, recommendations, and unanswered questions. American Thoracic Society. Am J Respir Crit Care Med. 2000;162:2341-51.

95. Serra-Batlles J, Plaza V, Morejón E, Comella A, Brugués J. Costs of asthma according to the degree of severity. Eur Respir J. 1998;12:1322-6.

96. Chung KF, Wenzel SE, Brozek JL et al. International ERS/ATS guidelines on definition, evaluation and treatment of severe asthma. Eur Respir J. 2014;43:343-73.

97. Contoli M, Kraft M, Hamid Q et al. Do small airway abnormalities characterize asthma phenotypes? In search of proof. Clin Exp Allergy. 2012;42:1150-60.

98. Dolhnikoff M, da Silva LFF, de Araujo BB et al. The outer wall of small airways is a major site of remodeling in fatal asthma. J Allergy Clin Immunol. 2009;123:1090-1097, 1097.e1.

99. Caramori G, Oates T, Nicholson AG et al. Activation of NF-kappaB transcription factor in asthma death. Histopathology. 2009;54:507-9.

100. Mauad T, Silva LFF, Santos MA et al. Abnormal alveolar attachments with decreased elastic fiber content in distal lung in fatal asthma. Am J Respir Crit Care Med. 2004;170:857-62.

101. Berry M, Hargadon B, Morgan A et al. Alveolar nitric oxide in adults with asthma: evidence of distal lung inflammation in refractory asthma. Eur Respir J. 2005;25:986-91.

102. Vignola AM, Chanez P, Campbell AM et al. Airway inflammation in mild intermittent and in persistent asthma. Am J Respir Crit Care Med. 1998;157: 403-9.

103. The ENFUMOSA cross-sectional European multicentre study of the clinical phenotype of chronic severe asthma. European Network for Understanding Mechanisms of Severe Asthma. Eur Respir J. 2003;22:470-7.

104. Moore WC, Bleecker ER, Curran-Everett D et al. Characterization of the severe asthma phenotype by the National Heart, Lung, and Blood Institute's Severe Asthma Research Program. J Allergy Clin Immunol. 2007; 119:405-13.

105. Usmani OS, Biddiscombe MF, Barnes PJ. Regional lung deposition and bronchodilator response as a function of beta2-agonist particle size. Am J Respir Crit Care Med. 2005;172:1497-504.

106. Johal B, Howald M, Fischer M, Marshall J, Venthoye G. Fine Particle Profile of Fluticasone Propionate/Formoterol Fumarate Versus Other Combination Products: the DIFFUSE Study. Comb Prod Ther. 2013;3:39-51.

107. Iwanaga T, Kozuka T, Nakanishi J et al. Aerosol Deposition of Inhaled Corticosteroids/Long-Acting $\beta 2$-Agonists in the Peripheral Airways of Patients with Asthma Using Functional Respiratory Imaging, a Novel Imaging Technology. Pulm Ther. 2017;3:219.

108. Hauber H, Taha R, Bergeron C, Migounov V, Hamid Q, Olivenstein R. Effects of hydrofluoroalkane and dry powder-formulated corticosteroids on sputum inflammatory markers in asthmatic patients. Can Respir J. 2006;13:73-8.
109. Busse WW, Brazinsky S, Jacobson K et al. Efficacy response of inhaled beclomethasone dipropionate in asthma is proportional to dose and is improved by formulation with a new propellant. J Allergy Clin Immunol. 1999;104:1215-22.

110. Yamaguchi M, Niimi A, Ueda T et al. Effect of inhaled corticosteroids on small airways in asthma: investigation using impulse oscillometry. Pulm Pharmacol Ther. 2009;22:326-32.

111. Juniper EF, Price DB, Stampone PA, Creemers JPHM, Mol SJM, Fireman P. Clinically important improvements in asthma-specific quality of life, but no difference in conventional clinical indexes in patients changed from conventional beclomethasone dipropionate to approximately half the dose of extrafine beclomethasone dipropionate. Chest. 2002;121:1824-32.

112. Goldin JG, Tashkin DP, Kleerup EC et al. Comparative effects of hydrofluoroalkane and chlorofluorocarbon beclomethasone dipropionate inhalation on small airways: assessment with functional helical thin-section computed tomography. J Allergy Clin Immunol. 1999;104:S258-267.

113. Boulet L-P, Bateman ED, Voves R, Müller T, Wolf S, Engelstätter R. A randomized study comparing ciclesonide and fluticasone propionate in patients with moderate persistent asthma. Respir Med. 2007;101:1677-86.

114. Hoshino M. Comparison of effectiveness in ciclesonide and fluticasone propionate on small airway function in mild asthma. Allergol Int. 2010;59:59-66.

115. Cohen J, Douma WR, ten Hacken NHT, Vonk JM, Oudkerk M, Postma DS Ciclesonide improves measures of small airway involvement in asthma. Eur Respir J. 2008;31:1213-20.

116. Scichilone N, Battaglia S, Sorino C et al. Effects of extra-fine inhaled beclomethasone/formoterol on both large and small airways in asthma. Allergy. 2010;65:897-902.

117. Vos W, De Backer J, Poli G et al. Novel functional imaging of changes in small airways of patients treated with extrafine beclomethasone/formoterol. Respiration. 2013;86:393-401.

118. Huchon G, Magnussen H, Chuchalin A, Dymek L, Gonod FB, Bousquet J. Lung function and asthma control with beclomethasone and formoterol in a single inhaler. Respir Med. 2009;103:41-9.

119. Ware JH, Hamel MB. Pragmatic trials--guides to better patient care? N Eng J Med. 2011;364:1685-7.

120. Sonnappa S, McQueen B, Postma DS et al. Extrafine Versus Fine Inhaled Corticosteroids in Relation to Asthma Control: A Systematic Review and Meta-Analysis of Observational Real-Life Studies. J Allergy Clin Immuno Pract. 2017;Sep 20.

121. Müller V, Gálffy G, Eszes N et al. Asthma control in patients receiving inhaled corticosteroid and long-acting beta2-agonist fixed combinations. A real-life study comparing dry powder inhalers and a pressurized metered dose inhaler extrafine formulation. BMC Pulm Med. 2011;11:40.

122. Price D, Small I, Haughney J et al. Clinical and cost effectiveness of switching asthma patients from fluticasone-salmeterol to extra-fine particle beclometasone-formoterol: a retrospective matched observational study of real-world patients. Prim Care Respir J. 2013;22:439-48.

123. Allegra L, Cremonesi G, Girbino G et al. Real-life prospective study on asthma control in Italy: cross-sectional phase results. Respir Med. 2012;106:205-14

124. Popov TA, Petrova D, Kralimarkova TZ et al. Real life clinical study design supporting the effectiveness of extra-fine inhaled beclomethasone/formoterol at the level of small airways of asthmatics. Pulm Pharmacol Ther 2013;26:624-9.

125. Schmidt O, Petro W, Hoheisel G, Kanniess F, Oepen P, Langer-Brauburger B. Real-life effectiveness of asthma treatment with a fixed-dose fluticasone/ formoterol pressurised metered-dose inhaler - Results from a non-interventional study. Respir Med. 2017;131:166-74.

126. Marth K, Spinola M, Kisiel J, Woergetter C, Petrovic M, Pohl W. Treatment response according to small airway phenotypes: a real-life observational study. Ther Adv Respir Dis. 2016;10:200-10. 